\title{
ISLAM DAN POLITIK KENEGARAAN PERSPEKTIF MUHAMMAD ARKOUN
}

\author{
Sumarkan \\ Fakultas Syariah IAIN Sunan Ampel Surabaya
}

\begin{abstract}
Abstrak: Tulisan ini akan menggambarkan tentang konsep negara Islam dari pemikiran Muhammad Arkoun. Untuk menata masa depan hubungan antar agama dan Negara di negeri-negeri Muslim tampaknya perlu dilakukan berapa hal penting: pertama, kaum politisi santri perlu terus meningkatkan kualitas pengalaman berpolitik (political experience) mereka di arena politik kenegaraan di masing-masing Negara. Terutama Negara yang bercorak nation-state. Kedua, pola pemikiran (etika) politik Islam yang masih berkutat pada landasan epistemologi klasik perlu ditransformasikan ke arah pemikiran yang secara epistemologis lebih bercorak sosial-empiris sesuai dengan tantangan zaman yang ada. Ketiga, umat Islam khususnya para politisi Muslim harus terus berupaya melepaskan diri dari kungkungan berpikir historis-romantis dan normatif-teologis-apologis, serta harus berani melakukan terobosan kontekstual yang antisipatif dengan masa depan peradaban dunia. Keempat, isu-isu politik khiläfah dan penegakan syariat Islam harus dikaji ulang, baik secara konseptual maupun relevansinya dengan konteks zaman, lebih khusus dengan realita sistem nation-state yang ada di berbagai belahan dunia Islam. Bukankah konsep khilafah pada hakikatnya lebih bersifat historis belaka, bukan sesuatu yang secara normatif Islam harus diwujudkan.

Kata Kunci: Islam, Politik, Khilafah, Negara, Pemerintahan
\end{abstract}

\section{Pendahuluan}

Perdebatan ilmiah mengenai Islam dan politik kembali menemukan momentumnya sejak tumbangnya kekhalifahan Islam Ottoman 1924. Sebelumnya literatur yang ada mengenai pendekatan Islam terhadap masalah kenegaraan baik dalam soal pemilihan imam, kualifikasi pemimpin amir dan tata administrasi kekhalifahan tidak meragukan integrasi Islam dalam politik, akan tetapi setelah itu muncul berbagai literature yang banyak dibaca 
kalangan umat Islam sehingga mengaburkan jati diri Islam dalam kehidupan masyarakat dan berbagai aspeknya.

Oleh karena itu sebenarnya dengan terbukanya studi-studi baru mengenai Islam dan politik, maka ada beberapa hal yang patut mendapatkan kaian untuk masa depan politik Islam. Pertama, definisi holistik menyeluruh Islam akan menyelesaikan kontradikisi dan pertentangan diantara umat Islam sendiri mengenai apa yang seharusnya dilakukan baik secara ilmiah maupun praktis dalam mengelola hal-hal kenegaraan atau hal-hal yang berkaitan dengan kekhalifahan, bila sudah berdiri di masa mendatang. Hasan Al Banna mengatakan politik segala hal yang berkaitan dengan memikirkan (dan bertindak) tentang persoalan internal dan eksternal ummat.

Konsep Islam yang menyeluruh mengenai kehidupan tergambar dalam $\mathrm{Al}$ Quran yang mengatur seluruh tindak tanduk dan prilaku mulai dari sosial, ekonomi dan kenegaraan. Bahkan dalam praktek Rasulullah SAW sendiri pengelolaan kekuasaan di Madinah dilembagakan dalam Piagam Madinah. Dalam konteks ini dapat dikatan bahwa, konsep dan contoh sebagaimana yang dilakukan Rasulullah tidak ada kontradiksi seperti terjadi di sebagian kalangan umat Islam. Kedua, mengingat asingnya keteribatan umat Islam dalam kehidupan politik kenegaraan maka untuk menghilangkan kecanggungan itu perlu dilakukan secara berangsur-angsur. Politik sebagai seni mengatur masyarakat untuk mencapai Ridha Allah seharusnya dipraktekkan oleh kalangan umat Islam yang komitmen dengan tujuan-tujuan Islami. Pengenalan partai politik berasas Islam dengan perangkat leadership, administrasi dan struktur yang modern akan memberikan rasa percaya umat kepada adanya sebuah konsep yang hidup dalam praktek. Amal yang kentara dalam mengatur kekuasaan yang adil oleh pelaku kenegaraan memberikan kemakmuran serta kepercayaan masyarakat terhadap Islam sebagai masa depan pengaturan politik. 
Ketiga, karena politik tidak hanya seni mengatur kekuasaan dalam tingkat sebuah entitas politik, maka studi dan praktek politik di era globalisasi perlu dilakukan di tataran internasional. Dengan semakin tipisnya batas territorial dan kedaulatan sebuah bangsa atau negara maka sudah selayaknya perlu dimasukkan faktor eksternal dalam interaksi politik lokal.

\section{Konstruksi Dasar Teori Politik Kenegaraan dalam Islam}

Ada dua teori modern tentang negara yang saling bertentangan. Pertama, teori Hegel yang mengatakan bahwa negara adalah perwujudan dari ide suci di muka bumi, di mana tiap warga negara dapat mengidentifikasikan martabat, status, dan arah kehidupannya. Citra Hegelian tentang negara adalah bahwa negara merupakan reinkarnasi ide suci dan karenanya ia harus berada di atas segalanya. Makin kuat suatu negara, makin baik bagi para warganya. Maka, tiap warga negara harus menyerahkan seluruh dedikasinya pada negara. Dengan kata lain, dalam konsep Hegelian, negara menjadi aparat yang didewakan, yang berhak menuntut apa pun dari para warganya.

Kedua, teori Marx. Walaupun ia bangga menjadi murid spiritual Hegel, tapi pendangannya tentang negara bertolak belakang dengan pandangan gurunya. Marx berpendapat bahwa negara pada hakikatnya adalah aparat atau mesin opresi, tirani, dan eksploitasi kaum pekerja oleh pemilik alat produksi dan pemegang distribusi kekayaan yang mencelakakan kelas pekerja. Jadi, tidak aneh bila kita temukan konsep mengenai layunya negara setelah terjadi revolusi sosialis dalam khazanah Marxisme. Artinya, setelah berlangsungnya revolusi sosialis, akan terbentuk suatu kediktatoran proletariat dan kemudian melalui kekuasaan kaum proletar itu, perbedaan kelas dapat dimusnahkan sampai terwujud masyarakat tanpa kelas. Dalam masyarakat tanpa kelas inilah negara sebagai aparat penindas kelas kapitalis akan layu dengan sendirinya, akan lenyap selamanya. Jika Hegel berpendapat bahwa kuat dan mekarnya negara berarti tercapainya 
cita-cita manusia, maka Marx justru menganggap lenyapnya negara sebagai summum bonum, kebajikan puncak, hal ini sungguh sangat berbeda dengan teori politik yang digagas oleh pemikir Islam yang diantaranya adalah al-Maududi.

Abu a'la al- Maududi berpendapat Pembentukan negara adalah hanya sebagian dari misi Islam yang agung. Membangun negara merupakan salah satu kewajiban agama. Oleh karena itu, negara yang sudah dibangun perlu dipelihara eksistensinya. Ditinjau dari kacamata teori politik modern atau teori politik sekular, teori politik Islam seperti yang dikembangkan oleh Maududi terlihat unik, bahkan mungkin ganjil. Keunikan teori politik Maududi terletak pada konsep dasar yang menegaskan bahwa kedaulatan ada di tangan Allah, bukan di tangan manusia. Jadi, berbeda dengan teori demokrasi pada umumnya yang menyatakan bahwa kedaulatan berada di tangan rakyat. ${ }^{1}$

Dalam konteks ini Maududi sangat memahami praktek "kedaulatan rakyat" sebagaimana yang dikemukakan oleh teori demokrasi. Siapa pun yang sedikit mendalami praktek demokrasi memang akan menyadari bahwa yang paling sering berlaku adalah hukum besi oligarki, yaitu sekelompok penguasa saling bekerja sama untuk menentukan berbagai kebijakan politik, sosial, dan ekonomi negara tanpa harus menanyakan bagaimana sesungguhnya aspirasi rakyat yang sebenarnya. Juga, tidak boleh kita lupakan bahwa sekelompok oligarch tersebut, yang berkuasa atas nama rakyat, selalu berusaha melestarikan dan memonopoli kekuasaan yang dipegangnya dengan selubung ideologi tertentu, dengan dalih konsensus nasional atau tindakan-tindakan semacamnya. Dan pada saat yang bersamaan, para oligarch itu memojokkan setiap oposisi yang menentang legitimasi pemerintahannya dengan tuduhan-tuduhan subversif, disloyalitas pada negara, dan sebagainya.

I Imam Ghazali Said, Idiologi Kaum Fundamentalis, Surabaya, PT. Diantama, 1998, hal 27

$122 \quad \begin{aligned} & \text { al-Daulah } \\ & \text { Vol. 2. no.2. Oktober } 2012\end{aligned}$ 
Teori politik modern (Barat) sangat mengagungkan "kehendak umum atau rakyat". Pemerintahan demokratis mencoba merealisasikan kehendak umum tersebut dalam praktik nyata dengan menciptakan peraturan dan perundang-undangan yang berpijak pada suara "mayoritas rakyat", meskipun mengabaikan aspirasi minotitas. Dengan demikian, kelompok minoritas tidak mendapatkan "kebebasan" seutuhnya, kendati eksistensinya legal dan memiliki pandangan-pandangan yang tepat dan benar (credible). Artinya, "pemerintahan yang berdasarkan pada kehendak rakyat" tidak akan pernah melahirkan kepuasan serta keikhlasan karena bisa saja mengabaikan nilai-nilai spiritual.

Di lain pihak, Islam memberi hak lebih tinggi bagi perealisasian "Kehendak Tuhan" melebihi berbagai kecenderungan serta nafsu yang sulit terkontrol, di mana ia sering kali terdapat pada mayoritas manusia, ${ }^{2}$ Islam menolak pengabaian nilai-nilai Ketuhanan dalam pembuatan hukum dan perundangundangan. Konsepsi Islam tentang Ketuhanan dan "Pemerintahan Ilahi" cukup luas, meliputi berbagai aspek kehidupan manusia di manapun ia berada. Sehingga, seharusnya kaum Muslimin bisa berperan sebagai pelindung bagi kelompok lainnya. Tentu saja hal ini memerlukan ketaatan total pada perundang-undangan dengan didasarkan pada keyakinan bahwa ia merupakan anugrah Allah; dan oleh karenanya tidak satu pun manusia berhak memperturutkan keinginan-keinginan atau hawa nafsunya untuk mendiktekan berbagai tindakan pelanggaran atas peraturan dan perundang-undangan itu.

Muncul pertanyaan, bagaimana manusia bisa berkomitmen secara total bahwa Tuhan mengatur seluruh aspek kehidupannya, ${ }^{3}$ sementara mereka mengambil aturan-aturan yang bersumber dari selain-Nya. Tidak satu pun manusia dapat menentang otoritas Ilahi, dan menganggap diri sebagai sekutu Allah SWT; juga tidak

\footnotetext{
${ }^{2}$ Lihat; Qs : 6: 116

${ }^{3}$ Lihat; Qs : 6 : 162
} 
satu pun yang dapat menggantikan kedudukan-Nya sebagai "Pencipta Aturan". Islam memperjuangkan kebenaran dan keadilan dalam berbagai aspek kehidupan manusia; dan kebenaran serta keadilan tersebut tidak eksklusif terspesialisasi pada masalah-masalah sosial, hukum, budaya, politik, dan keuangan, tetapi juga sandang, pangan dan papan, di mana kesemuanya itu dapat meningkatkan martabat manusia itu sendiri.

Kendati berbagai upaya telah dicurahkan oleh sejumlah pemikir atau peneliti untuk memahami misteri manusia, namun aspek-aspek yang telah berhasil mereka temukan masih saja sangat terbatas. Dr Alexis Carrel mengatakan, "Manusia telah melakukan upaya-upaya dahsyat guna memahami dirinya. Meski telah diperoleh hasil-hasil observasi berharga yang dikumpulkan oleh para ilmuwan, filsuf, sastrawan, dan mistikus besar yang hidup dalam berbagai zaman, tetapi tetap saja masih terbatas atau terkungkung pada aspek tertentu. Manusia tidak akan pernah memahami dirinya secara utuh. Pemahaman kita hanya sebatas pengenalan bahwa manusia merupakan susunan dari bagian-bagian yang beragam; dan bahkan bagian-bagian tersebut dicitrakan dari metode kita sendiri. Setiap orang dipengaruhi oleh prosesi aneka kekhawatiran atau ketakutan, di mana hal tersebut akan mengarahkan mereka kepada sebuah realitas yang tidak diketahui." 4

Dengan demikian, baik sistem pemerintahan Barat (baca: liberalisme atau neoliberalisme) maupun Timur (baca: komunisme atau pun sosialisme) jelas gagal dalam penyamarannya di balik isu "kehendak umum atau rakyat", "mekanisme atau sistem parlementer" dan "perwakilan rakyat". Keduanya merupakan sistem yang tidak adil karena mengabaikan ketentuan Ilahi (basa: sunnatullah), yang telah disiapkan oleh Yang Maha Kuasa untuk kebaikan manusia itu sendiri.

4 "Western Civilization Trough Muslim Eyes" (1977) oleh Forum Studi Politik dan Teknologi Nasional, hal 4 


\section{Biografi Mohammaed Arkoun}

Mohammed Arkoun lahir tanggal 1 Februari 1928 di TaorirtMimoun di Kabilia, suatu daerah pegunungan berpenduduk Berber di sebelah Timur Aljir. Wilayah Kabilia (al-Qabail) terbagi kepada dua, yaitu Kabilia Besar (dengan luas sekitar satu juta hektar) dan Kabilia kecil. Penduduknya hidup dari hasil pertanian (buah tin dan zaitun), menggembala ternak, dan berdagang kerajinan tangan. Sedangkan Berber adalah panggilan untuk penduduk yang tersebar di Afrika bagian utara, dari Libya sampai Samudera Atlantik. ${ }^{5}$

Latar belakang sosial tersebut, membuat Mohammed Arkoun bergelut dalam tiga bahasa, yaitu bahasa kabilia, bahasa Arab dan bahasa Perancis. Pertama, adalah salah satu bahasa Berber yang diwarisi Afrika Utara dari Zaman pra-Islam dan pra-Romawi. Kedua, adalah bahasa yang dibawa oleh arus ekspansi Islam sejak abad pertama hijriyah. Ketiga, adalah bahasa Perancis yang dibawa oleh bangsa yang yang menguasai Aljazair antara tahun 1830 sampai dengan $1862 .{ }^{6}$

Muhammad Arkoun mengawali pendidikannya di sekolah dasar di desa asalnya, Kabilia. Kemudian ia melanjutkan sekolah menengahnya di kota pelabuhan Oran, sebuah kota utama di AlJazair bagian barat jauh dari Kabilia. Dari tahun 1950 sampai 1954 ia belajar bahasa dan sastra Arab di universitas Aljir, sambil mengajar bahasa arab pada sebuah sekolah menengah atas (SMA) di al-Haurach di daerah pinggiran ibu kota Aljazair.

Di tengah perang pembebasan Aljazair dan pemerintah kolonial perancis (1954-1962), Mohammed Arkoun mendaftarkan diri sebagai mahasiswa di Paris. Sejak itulah ia menetap di Perancis. Pergaulannya dengan peradaban Perancis yang sudah dimulai ketika duduk di sekolah dasar yang berpola Perancis, di

${ }^{5}$ Johan Hendrik Mouleman, "Riwayat Hidup dan Latar Belakang Mohammad Arkoun" Kata Pengantar dalam Mohammad Arkoun, Nalar Islam dan Nalar Modern:: Berbagai Tantangan dan Jalan Baru, terj. Rahayu S. Hidayat (Jakarta: INIS, 1994 ) hal. 19

${ }^{6}$ Lihat dalam Johan Mauleman, Pengatar dalam buku nalar Islam, hal 24, lihat juga Dasar-dasarb semiotika, hal. 57 
desa kelahirannya, kini berlanjut semakin intensif, namun, bidang utama studi dan penelitian (area of concern) Arkoun tidak berubah, yaitu bahasa dan sastra Arab. Pada proses perkembangannya ia semakin mempertinggi kuantitas perhatiannya terhadap pemikiran Islam. Karena itu ciri utama pemikiran Arkoun adalah pemaduan khas antara Barat dan Islam. ${ }^{7}$

Pada 1969-1972, Mohammed Arkoun pindah mengajar ke Universitas Lyon dan kemudian kembali ke Paris serta menjabat Professor bahasa Arab dan peradaban Islam di Universitas Paris (1972-1977), ia juga sering menjadi dosen tamu di University of California di Los Angeles, lembaga Kepausan untuk studi Arab dan Islam di Roma; Universitas Katolik Louvain la-Nenue di Belgia, Primeton University dan Temple University di Philadelphia, Arkoun juga pernah memberikan kuliah di Rabut Fez, Aljir, Tunis, Damaskus, Beirut, Teheran, Berlin, Kolumbia, dan Denver.

Karya-karya Mohammed Arkoun yang paling penting adalah Contribution a l'etude de l'Humanisme Arabe au IV/X siecle : Miskawayh philosophe et historien ; La pensee Arabe. Karya-karya lain Arkoun merupakan kumpulan artikelnya dan telah dipublikasikan dalam beberapa majalah, antara lain Lectures $d u$ Coran (Telaah tentang Qur'an), Pour une crithique de la raison Islamiqhue; Essais sur lapensee Islamighue. Sedangkan buku-buku Arkoun selain yang disebutkan diatas antara lain Aspects de la pensee musulmane classique.

Adapun karya Muhammed Arkoun yang lain adalah L'Islam, hier, demain (Islam, Kemarin dan Hari Esok). Buku ini merupakan karya bersama Louis Gardet; L'Islam, Religion et Societe, Al-Fikr alIslamy : Qiraah Ilmiyyah; AL-Fikr al-Islamy: Naqd wa al-Ijtihad; AlIslam : al-Akhlaq wa al-Siyasah; Min Faishal al-Tafriqah ilaa fasl al-

Johan Hendrik Mouleman, Nalar Islam dan Nalar Modern: Memperkenalkan Pemikiran Muhammad Arkoun, Ulumul Qur'an, Jurnal Ilmu dan Kebudayaan, Vol. IV. No. 4, Tahun 1993 
Maqal.... Aina huwa al-Fikry al-Islamy al-Muashir; Tarikhy al-fikr alAraby al-Islamy. ${ }^{8}$

\section{Konstruksi Pemikran Politik Muhammad Arkoun}

Dalam penelusuran yang peneliti lakukan, pemikiran Etika politik Arkoun dapat dikemukakan dalam enam subtema penting yakni: pertama, dimensi wewenang (authority) dan kekuasaan (power) dalam diri Nabi Muhammad SAW yang menurut Arkoun antara keduanya tidak bersifat dikotomik - sebagaimana dalam tradisi politik di dunia Barat yang bercorak Cartesian - tetapi lebih simbiotik. Kedua, terkait dengan gagasan pembangunan maupun perubahan sosial, Arkoun menekankan pentingnya faktor agama sebagai alat "pengubah dunia" lebih dari sekedar menafsirkannya. Arkoun juga menekankan betapa pentingnya keterkaitan pembangunan dan perubahan itu dengan wilayah hukum. Sembari menegaskan bahwa nalar politik Islam yang dijadikan landasan yuridis pembangunan bukanlah nalar politik yang bercorak sloganistik-formalistik sebagaimana yang banyak dipropagandakan oleh muslim fundamentalis, tetapi juga bukan sekedar upaya liberalisasi pemikiran keislaman yang terbatas pada wacana keagamaan yang terkadang juga terjebak pada pola pikir Cartesian dan terkesan tidak memiliki orisinalitas pemikiran. Lebih dari itu Arkoun menekankan betapa pentingnya wacana liberasi pemikiran politik Islam diterjemahkan ke dalam proses transformasi sosial.

Ketiga, tentang relasi agama dan negara, Arkoun menyatakan bahwa kebanyakan negeri-negeri Muslim - terutama di Arab mengalami berbagai benturan keras akibat penjajahan asing. Faktor inilah yang membuat umat Islam menjadikan agama sebagai icon perjuangan ideologi politik. Bagi Arkoun, keterkaitan antara agama dan Negara secara historis sangat bervariasi. Secara

${ }^{8}$ Johan Hendrik Mouleman, "Riwayat Hidup dan Latar Belakang Mohammad Arkoun" Kata Pengantar dalam Mohammad Arkoun, Nalar Islam dan Nalar Modern:: Berbagai Tantangan dan Jalan Baru,

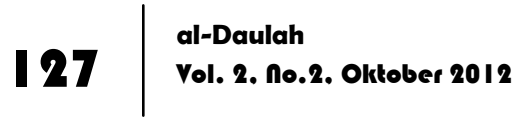


faktual, Nabi tidak meninggalkan pewaris tahta, dan masalah khilãfah juga termasuk wilayah yang diperdebatkan di kalangan Muslim (khiläfiyyah). Oleh sebab itu Arkoun menyatakan bahwa konsep syũrã sebenarnya identik dengan demokrasi. Sistem demokrasi parlementer bisa diterima sepanjang bisa mengakomodasi nilai-nilai universal dari ajaran syariat Islam. Dengan sistem syura atau demokrasi ini, penerapan syariat Islam lebih bersifat rasional-diskursif dan substantif, ketimbang tekstualnormatif. Tentang gagasan khilãfah, bagi Arkoun, itu merupakan sebuah gagasan yang sangat utopis. Arkoun berargumen bahwa isu khilãfah ini tidak ada kesepakatan di kalangan umat, karena berbeda penafsiran agama serta latar belakang sosial budaya masing-masing negeri Muslim. Selain itu, intervensi Negara dalam wilayah keagamaan akan berdampak pada manipulasi simbolsimbol keagamaan dan akan mereduksi kebebasan beragama dan berpolitik masyarakat. Bahkan akan membuka peluang terjadinya kolusi antara penguasa dan otoritas keagamaan. Bagi Arkoun, otoritas keagamaan dan politik kenegaraan harus berbeda, walaupun tetap ada hubungan. Arkoun menggambarkan, bila Negara bagai sebuah bingkai, maka agama yang menjadi isinya.

Keempat, tentang masyarakat kitab dan pluralisme. Arkoun mendorong terwujudnya proses kehidupan yang lebih rasional dan demokratis, sekaligus mendorong munculnya komunitas Muslim maupun non Muslim yang saling menghargai pluralitas dan keterbukaan karena diakui adanya penghargaan terhadap aneka pemahaman teks keagamaan secara lebih terbuka, baik secara internal (hubungan antar komunitas umat Islam) maupun eksternal (hubungan antar umat Islam dengan non Muslim). Hasil akhirnya sudah dapat diprediksi akan terwujudnya masyarakat kitab yang toleran, terbuka dan saling menjunjung tinggi nilai persaudaraan dan perdamaian, sebagai wujud konkrit dari tujuan akhir diturunkannya wahyu di muka bumi ini. Menurut Arkoun, kolonialisme secara fisik memang telah berakhir, namun pemikiran kita masih terjajah, tidak ikut modernitas yang ditandai 
oleh kebebasan berpikir. Ini yang harus dilepaskan oleh umat Islam. Dengan tetap mempertahankan pluralisme, seseorang akan tetap menjadi kritis, baik dalam filsafat, teologi maupun politik. Pluralisme inilah yang hilang dalam Islam. Islam dalam tataran teologis-filosofis, harus mempertahankan kebebasan bagi setiap Muslim untuk berpartisipasi dalam ijtihad. Pemahaman ini penting untuk membangun demokrasi di Negara-negara Islam dan untuk memulihkan kembali kebebasan berpikir dalam Islam.

Kelima, tentang demokrasi dan modernitas. Menurut Arkoun, secara historis antara kaum Muslim dengan Barat sebenarnya memiliki pengalaman yang sama dalam masalah peradaban yang demokratis-humanis, sebagaimana tercermin pada era keemasan sejarah Islam. Tradisi demokrasi di Barat pada hakikatnya juga merupakan warisan humanis dari peradaban Islam sebagaimana yang tercermin dari khazanah pemikiran Ibnu Rusyd, Ibnu Sina, dan lain-lain. Arkoun juga mengemukakan bahwa terjadinya ketegangan antara Barat dan Islam pada dasarnya lebih disebabkan pengaruh dari endapan sejarah pemikiran - baik di kalangan Islam maupun Barat - yang umumnya bersumber pada literatur-literatur abad pertengahan yang polemis-apologis. Selain itu, Arkoun mengemukakan bahwa munãzharah merupakan jantung demokrasi. Ketika antar warga masyarakat saling berbicara dan bertukar pikiran, mereka saling berhadapan muka (munãzharah). Dalam Islam memang ada yang disebut munãzharah untuk bertukar pikiran. Tidak ada demokrasi tanpa munãzharah, karena dalam munãzharah setiap orang bebas mengeluarkan pendapat.

Keenam, tentang sekuler, sekularisasi dan sekularisme. Menurut Arkoun, untuk mengantisipasi sekularisme dalam politik bukan berarti umat Islam harus kembali kepada "agama tradisional", tapi lebih dari itu amat dibutuhkannya formulasi baru tentang humanisme spiritual yang sudah barang tentu harus diperbandingkan dengan berbagai faham humanisme dan kebebasan yang telah ada, dan dalam perspektif agama-agama. 
Sekularisasi di mata Arkoun bukanlah menafikan agama, tetapi lebih pada perluasan ruang kebebasan berfikir secara kultural, historis dan ilmiah, tidak semata-mata ideologis dan teologis. Bagi Arkoun, istilah sekularisasi perlu dibedakan dalam konteks teologis atau politis (hubungan Islam dan negara). Sekularisasi bukanlah usaha menafikan konsep spiritualitas agama, sehingga terjadi kekosongan makna dalam kehidupan sosial kemasyarakatan sebagaimana yang terjadi di Barat dewasa ini, tetapi lebih bersifat usaha meninggalkan pola-pola pemahaman ajaran agama yang sudah out of date dengan perkembangan zaman. Dalam kaitan ini sekularisasi sejalan dengan kontekstualisasi nilainilai ajaran Islam.

\section{Konstruksi Nalar Politik Kenegaraan Mohammed Arkoun}

Wacana tentang hubungan antara agama dewasa ini menjadi hangat kembali di dunia Muslim sehingga muncul, apa yang disebut Bassam Tibi, dengan fenomena repolitisasi Islam, yang mengandung makna bahwa Islam dijadikan landasan ideologi politik. ${ }^{9}$ Menurut Bassam Tibi, gejala repolitisasi Islam ini paling tidak disebabkan oleh dua hal, pertama, umat Islam sedang mengalami krisis identitas. Kedua, adanya krisis sosial-ekonomi dan gejala pemiskinan yang melanda umat Islam, sehingga keadaan ini menjadi lahan subur bagi tumbuhnya ideologiideologi keagamaan yang menawarkan janji-janji pembebasan.

Tetapi sayangnya, Islam sering kali ditawarkan sebagai sebuah sistem aturan politik secara eksklusif bahkan dalam konteks tertentu sebagai legitimator sebuah kekuasaan. ${ }^{10}$ Namun kurang disadari, bahwa bila Islam telah bersinergi menjadi sebuah ideologi politik akan berdampak pada munculnya "ketakutan

9 Lihat Bassam Tibi, Krisis Modern dalam Peradaban Islam, terj. Yudian W. Asmin, et all (Yogyakarta: Tiara Wacana, 1994), hlm. 163.

10 lihat, Syafiq Hasyim, "Islam dan Politik: Sebuah Studi Keterkaitan, Telaah Awal Mengenai Pemikiran Mohammed Arkoun", dalam Tradisi, Kemodernan dan Metamodernisme, Memperbincangkan Pemikiran Mohammed Arkoun (Yogyakarta: LKiS, I996), hlm. I3I. 
ideologis-politis" - berdampak pada munculnya gejala Islamophobia -dari orang lain (baca: non-Muslim), karena tanpa disadari pada saat yang sama akan mudah dijadikan "alat pemukul" bagi komunitas lain. Sebenarnya, bila dikritisi lebih jauh, Islam memang dapat digunakan sebagai sebuah ideologi politik yang kaku, namun bisa juga dijadikan sebagi solusi etis dan moral secara lebih demokratis. ${ }^{11}$ Namun untuk yang terakhir ini membutuhkan pemikiran dan kerja politik yang serius, yang memang tidak banyak orang bersedia menekuninya.

Menurut peneliti, disamping dua hal di atas, ada beberapa hal lain yang menyebabkan munculnya repolitisasi atau ideologisasi Islam di atas, pertama, adanya fakta hegemoni kekuasaan Barat (baca: AS) terhadap banyak negeri-negeri Muslim. Fakta ini menyebabkan dunia Muslim menjadi bersifat defensif terhadap terhadap Barat, dan medium pembangkit motivasi untuk memperkuat daya dukung perlawanan itu adalah Islam sebagai sebuah ideologi perjuangan. Kedua, dalam saat yang sama, mayoritas umat - terutama para aktivisnya - kurang memiliki pemahaman yang rasional dan kritis ketika melihat Islam dalam konteks perjuangan politik umat. Kebanyakan para aktivis tersebut menjadikan Islam sebagai sebuah ideologi tandingan terhadap ideologi Barat (baca: Kapitalisme) sekaligus merupakan jalan pintas perjuangan yang dianggap ringan dan cepat saji, sekaligus melakukan mobilisasi umat melalui pemanfaatan simbol-simbol keislaman. Ketiga, sudah barang tentu tak dapat pula dipungkiri adanya semacam political interest yang tertanam dalam benak sebagian aktivis Muslim dalam memanfaatkan simbol-simbol keislaman di panggung pragmatisme politik.

Mohammed Arkoun sendiri dalam memberikan kata pengantar untuk bukunya Nalar Islami dan Nalar Modern: Berbagai Tantangan dan Jalan Baru menyatakan bahwa: Islam Arab sejak abad XIX telah menderita berbagai benturan keras yang banyak

"Ibid, hlm. I32. Bandingkan M. Din Syamsuddin, "Usaha Pencarian Konsep Negara dalam Pemikiran Islam", Ulumul Qur'an, 4 (I993), 2, hlm. 4-9

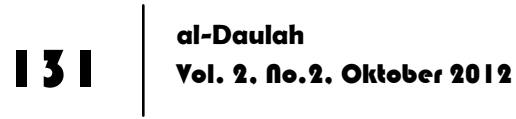


jumlahnya karena terjadinya hegemoni politik, ekonomi dan budaya oleh bangsa Eropa di kawasan Laut Tengah; penjajahan, kemudian berbagai perang kemerdekaan bangsa telah memaksa kaum Muslim untuk bertopang pada agama di dalam mengembangkan suatu ideologi perjuangan. ${ }^{12}$

Lebih lanjut Arkoun mengharapkan bila negeri Muslim seperti Indonesia - bisa mengembangkan Islam yang bebas dari kungkungan logosentrisme politik sebagaimana yang mendera Arab Islam di atas. Selama kunjungan singkatnya ke Indonesia (Jakarta dan Yogyakarta) Arkoun merasa optimis bila Indonesia bisa menjadi teladan bagi dunia Islam dalam upaya melahirkan para intelektual Muslim yang dapat merespon modernitas secara cerdas dan akademis. Para pemikir Islam Indonesia diharapkan oleh Arkoun dapat melakukan upaya "peningkatan menuju ruangruang baru bagi pemahaman, penafsiran dari segala masalah yang ditimbulkan oleh apa yang kita sebut kemodernan". ${ }^{13}$

Adapun tentang keterkaitan agama (Islam) dan politik (siyãsah) ini sebenarnya disinggung juga oleh Arkoun dalam tulisannya "Madkhal li dirãsah ar-rawãbit baina al-Islãm wa alsiyãsah" dalam bukunya al-Fikr al-Islãmi, Qirã'ah 'Ilmiyyah, Arkoun berpendapat bahwa relasi Islam dan politik dapat didekati melalui dua pendekatan. Pertama, pendekatan historis yang konvensional yang bersifat deskriptif. Kedua, pendekatan pemikiran dan perenungan kembali tentang berbagai problematika dan kesulitan yang pernah muncul berkaitan dengan Islam dan politik, dimulai sejak pengalaman misi kenabian Muhammad s.a.w. di Mekah, maupun pengalaman politisnya di Madinah. ${ }^{14}$

\footnotetext{
${ }^{12}$ Lihat Mohammed Arkoun, Nalar Islami, hlm. 39

13 Ibid. Bandingkan pula dengan Nurcholish Madjid, yang mengulas secara panjang lebar tentang relasi Islam dengan kemodernan, dalam karyanya, Islam Doktrin dan Peradaban, Sebuah Telaah Kritis tentang Masalah Keimanan, Kemanusiaan, dan Kemoderenan (Jakarta: Paramadina, 1992), hlm. 450-525

${ }^{14}$ M. Arkoun, Al-Fikr al-Islämy, Naqd wa litihãd, terj. Hasyim Shalih (Beirut: Dar al-Saqi, cet.II, 1992), hlm. I 43.
} 
Dalam karyanya Al-Islãm al-Akhlãq wa As-Siyãsah Arkoun menyatakan tentang teori Daulah Islamiyah dalam Islam sebenarnya sangat variatif. Secara common sense, umumnya umat berkeyakinan bahwa setiap Muslim berkewajiban untuk mentaati segala perintah Allah tanpa reserve. Setiap komunitas Muslim wajib mentaati syariat sang Khaliq sekaligus hukum yang dibawa oleh Nabi Muhammad s.a.w. Secara normatif-historis, manusia pertama Adam as diturunkan Tuhan ke bumi berfungsi sebagai khalifah yang melebihi kedudukan syetan bahkan malaikat sekalipun. Walaupun dalam realitas historisnya Adam sang khalifah pernah tergoda, karena kelemahan manusia, oleh godaan syetan, namun akhirnya Adam kembali bertobat dan tunduk dengan syariat Ilahiah yang sebenarnya. Inilah daulah pertama dalam sejarah kemanusiaan di alam ini. Kedaulatan ilahiah ini terus berlanjut pada masa para Nabi berikutnya sesudah Adam as, terutama Nuh, Musa, Ibrahim, Isa hingga Muhammad s.a.w. Jadi semua Nabi, demikian keyakinan mayoritas Muslim, telah membangun apa yang disebut dengan daulah ilahiah yang berdasarkan syariat Islam.

Dari sinilah muncul ide kesatuan umat (al-mujtama' al-wahĩd) dimana setiap Muslim memiliki ketundukan totalitas pada syariat ilahiah. Barangsiapa yang membangkang atau menolak konsep ketundukan ilahiah ini, mereka tidak akan mendapat tempat di syurga pada hari akhirat nanti. Lebih lanjut Arkoun mengemukakan pandangan yang diyakini mayoritas Muslim dengan menyatakan bahwa fenomena ketundukan ilahiah di atas telah menjadi semacam rujukan dogmatis sejak dulu hingga sekarang.

Dalam artikelnya "Ad-Daulah wa al-Fard fi al-Mujtama' alIslãmy",15 Arkoun mengutip pendapat as-Sayyid Muhammad

\footnotetext{
${ }^{15}$ Bandingkan Mumtaz Ahmad (ed), Masalah-masalah Teori Politik Islam, terj. Ena Hadi (Bandung: Mizan, 1993), hlm. I 17- I26. Pandangan Rahman tentang ulasan ini dapat dilihat dalam, Fazlur Rahman, "A Recent Controversy over the Interpretation of Syura", History of Religion, No. 4, Vol. 4/Mei 1981, p. 293.
} 
Hakim Sa'id yang menyatakan bahwa konsep syũrã identik dengan konsep demokrasi. Dalam sistem syũrã atau demokrasi meniscayakan adanya majelis perwakilan rakyat yang memiliki wewenang untuk mengintrodusir pemikiran dalam perumusan syariat Islam secara rasional-kontekstual, tidak semata-mata normatif-tekstual.

Berdasarkan keterangan di atas, sangat wajar bila Arkoun menyatakan bahwa ide Negara Islam merupakan pandangan yang sangat utopis. Untuk lebih jelasnya kita kutip wawancara Arkoun sebagai berikut:

“Hingga hari ini tidak ada kesepakatan di antara umat Islam tentang defenisi Negara Islam. Jadi, sangat sulit untuk berbicara tentang Negara Islam. Sebab, setiap individu mempunyai interpretasi berbeda dalam memahami al-Qur'an. Perbedaan tafsir itu karena setiap individu memiliki latar belakang budaya yang berbeda dan memiliki permasalahan lokal yang berbeda. Jadi, Negara Islam adalah sebuah utopia, sesuatu yang kita inginkan tetapi mustahil untuk bisa diwujudkan. Kita tidak memiliki contoh. Ambillah misal Negara Iran. Khomeini menciptakan sebuah Negara yang ia klaim sebagai Negara Islam. Toh ia tidak bisa menyelesaikan persoalan teologis antara Islam Syiah dan Sunni. Karena itu, Khomeini menciptakan sebuah Negara nasionalis Iran, bukan sebuah Negara Islam. Lihat apa yang terjadi di Iran sekarang. Semua pihak menuntut iklim yang lebih demokratis. Itu sebabnya kita perlu mengelaborasi teori modern.

Menurut asumsi sementara, "Islam swasta" lebih langgeng ketimbang "Islam Negara" (resmi). Kita dapat belajar dari masyarakat Inggris yang lebih independen dan dapat melahirkan masyarakat yang swa-kritis dan kreatif, ketimbang misalnya, masyarakat Perancis yang serba tergantung pada Negara (sentralistik). ${ }^{16}$

\footnotetext{
${ }^{16}$ Bandingkan dengan Francis Fukuyama, Trust: The Social Virtues and the Creation of Prosperity (New York: Penguin Book, 1995), p.39
} 
Menurut peneliti, konsep Negara agama (religion state) melalui pelaksanaan semacam syariat Islam/Kristen dan lainnya misalnya - haruslah bersifat inklusif, bukan eksklusif dan bertumpu pada eksplorasi nilai-nilai keagamaan yang universal melalui jalur-jalur yang demokratis. Dengan demikian, semua penganut agama akan merasa dapat menerima tanpa dibayangi oleh ketakutan secara ekstrim-eksklusif dan fundamentalistik. Lebih jauh lagi, upaya etatisme (penegaraan) agama sejauh mungkin dapat dihindari, karena etatisme akan berdampak pada pengistimewaan agama tertentu. Di masa mendatang, pelembagaan nilai-nilai keagamaan secara esensial-substantif lebih relevan untuk sebuah Negara modern. Bentuk kenegaraan seperti ini bisa disebut dengan religious state (bukan religion state). Kita sebut dengan religious state sebagai sintesis atau alternatif dari bentuk Negara teokrasi maupun secular democracy. Model religious state ini mungkin merupakan jalan tengah yang dapat meredam ketegangan ideologis-politis yang berkepanjangan di berbagai negeri Muslim, antara elite politik nasionalis-sekulardemokrasi dengan politisi Muslim yang cenderung terjebak dengan pandangan Islamisme. ${ }^{17}$

Pemikir lainnya, Dr. Inayatullah (anggota Komisi Hak-hak Asasi Manusia Pakistan) menyatakan pula bahwa konflik agama dan Negara memang tak dapat dihindari, karena keduanya berusaha mempengaruhi masyarakat. Negara modern, katanya, harus diarahkan pada penghargaan terhadap kemanusiaan. Menurut Inayatullah, ada dua model hubungan antara agama dan Negara. Model pertama, hubungan tak langsung. Wujudnya, norma agama terserap dalam level Negara. Misalnya, norma persamaan dan kebebasan. Eksponen agama di sini tak perlu langsung ikut mengelola Negara. Model kedua, eksponen agama bekerjasama dengan elit Negara dalam politik. Pola demikian,

${ }^{17}$ Lihat "Islamism: Islam as a master signifier", dalam Bobby S. Sayyid, A Fundamental Fear, Eurocentrism and the Emergence of Islamism, London \& New York: Zed Books Ltd., 1997, p. 46-47.

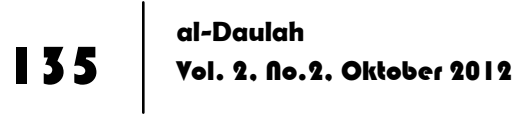


dalam pengalaman Pakistan, menimbulkan problem serius. Pada level ini akan terjadi eksploitasi slogan agama untuk justifikasi politik. Dalam kenyataannya, Pakistan Negara terkorup meskipun membawa nama agama.

Masih tentang relasi agama dan Negara ini, Masdar Mas'udi, cendekiawan Muslim Indonesia, mengidentifikasi ada empat aspek Islam yang bisa terkait dengan Negara. Pertama, aspek hukum privat (pernikahan dan waris). Kedua, aspek ritual kolektif (penentuan hari lebaran, zakat dan haji). Ketiga, aspek moral (keadilan, permusyawaratan, persamaan, dan persatuan kemanusiaan). Keempat, aspek hukum publik (pidana dan tata Negara). Menurut Masdar, kontroversi antara Islam dan Negara lebih banyak terkait dengan aspek yang keempat. Tiap Negara Islam akan selalu mendeklarasikan pemberlakuan hukum Islam, seperti tampak di Arab Saudi, Pakistan, dan Sudan. Sebagai perbandingan, di sini peneliti ingin menambahkan, khusus untuk Indonesia agak lain, Indonesia sebagai nation state, namun di daerah-daerah tertentu telah diberlakukan syariat Islam, seperti: Aceh, Banten dan Sulawesi Selatan. ${ }^{18}$ Keunikan pemikiran dan ekspresi politik keagamaan Islam di Indonesia terletak pada pernyataan "pelaksanaan syariat Islam tanpa khilafah dan Negara Islam". Apakah fenomena ini sebagai fenomena yang bersifat temporer, atau menjadi sebuah fenomena yang permanen di masa mendatang, atau lebih mencerminkan pada adanya ketidakjelasan konstitusional di Indonesia pasca reformasi. Untuk ini perlu penelitian tersendiri tentunya.

Menurut peneliti, untuk menata masa depan hubungan antar agama dan Negara di negeri-negeri Muslim tampaknya perlu dilakukan berapa hal penting: pertama, kaum politisi santri perlu terus meningkatkan kualitas pengalaman berpolitik (political experience) mereka di arena politik kenegaraan di masing-masing Negara. Terutama Negara yang bercorak nation-state. Kedua, pola

${ }^{18}$ Bandingkan dengan, Robert W. Hefner, Civil Islam, hlm. I72




pemikiran (etika) politik Islam yang masih berkutat pada landasan epistemologi klasik perlu ditransformasikan ke arah pemikiran yang secara epistemologis lebih bercorak sosial-empiris sesuai dengan tantangan zaman yang ada. Ketiga, umat Islam khususnya para politisi Muslim harus terus berupaya melepaskan diri dari kungkungan berpikir historis-romantis dan normatif-teologisapologis, serta harus berani melakukan terobosan kontekstual yang antisipatif dengan masa depan peradaban dunia. Keempat, isu-isu politik khilãfah dan penegakan syariat Islam harus dikaji ulang, baik secara konseptual maupun relevansinya dengan konteks zaman, lebih khusus dengan realita sistem nation-state yang ada di berbagai belahan dunia Islam. Bukankah konsep khilafah pada hakikatnya lebih bersifat historis belaka, bukan sesuatu yang secara normatif Islam harus diwujudkan. ${ }^{19}$

Menurut peneliti, secara umum, isu penegakan syariat Islam lebih relevan dengan menggunakan konsep syariat substantif ketimbang eksklusif. Model syariat substantif lebih dapat mengakomodasi atau mendamaikan dua tuntutan yang berbeda: warga Negara yang nasionalis-sekuler maupun kelompok Islam fundamentalis. Negara bangsa - seperti Indonesia misalnya - lebih tepat menggunakan konsep syariat Islam yang substantif, agar pola ketegangan ideologis-politis yang sudah lama berlangsung antara kaum nasionalis-sekuler dengan Muslim fundamentalis segera bisa terpecahkan. Sudah saatnya pola berpikir umat yang lebih bersifat ideologis-politis ditransformasikan ke arah berpikir yang lebih akademis.

\footnotetext{
${ }^{19}$ Pembahasan yang luas mendalam tentang konsep khilafah ini bisa dilihat dalam, Patricia Crone and Martin Hinds, God's Caliph, Religious authority in the first centuries of Islam, Cambridge: university of Cambriidge Oriental publications, 1986.
} 


\section{Daftar Pustaka}

Imam Ghazali Said, Idiologi Kaum Fundamentalis, Surabaya, PT. Diantama, 1998.

Johan Hendrik Mouleman, Riwayat Hidup dan Latar Belakang Mohammad Arkoun, Kata Pengantar dalam Mohammad Arkoun, Nalar Islam dan Nalar Modern: Berbagai Tantangan dan Jalan Baru, terj. Rahayu S. Hidayat (Jakarta: INIS, 1994 ).

Johan Hendrik Mouleman, Nalar Islam dan Nalar Modern: Memperkenalkan Pemikiran Muhammad Arkoun, Ulumul Qur'an, Jurnal Ilmu dan Kebudayaan, Vol. IV. No. 4, Tahun 1993.

Bassam Tibi, Krisis Modern dalam Peradaban Islam, terj. Yudian W. Asmin, et all , Yogyakarta: Tiara Wacana, 1994.

Syafiq Hasyim, Islam dan Politik: Sebuah Studi Keterkaitan, Telaah Awal Mengenai Pemikiran Mohammed Arkoun, dalam Tradisi, Kemodernan dan Metamodernisme, Memperbincangkan Pemikiran Mohammed Arkoun, Yogyakarta: LKiS, 1996.

Nurcholish Madjid, Islam Doktrin dan Peradaban, Sebuah Telaah

Kritis tentang Masalah Keimanan, Kemanusiaan, dan Kemoderenan, Jakarta: Paramadina, 1992.

Abul A'la al-Maududi, The Islamic Law and Constitution, Pakistan, Lahore: Islamic Publication Ltd, 1975.

M. Arkoun, Al-Fikr al-Islãmy, Naqd wa Ijtihãd, terj. Hasyim Shalih, Beirut: Dar al-Saqi, cet.II, 1992.

Ali Abd. Raziq, al-Islãm wa Ushũl al-Hukm, Kairo: Mathba'ah Misra Syirkah Musahamah Mishriyyah, 1925.

Mumtaz Ahmad (ed), Masalah-masalah Teori Politik Islam, terj. Ena Hadi (Bandung: Mizan, 1993).

Fazlur Rahman, A Recent Controversy over the Interpretation of Syura, History of Religion, No. 4, Vol. 4/Mei 1981.

Francis Fukuyama, Trust: The Social Virtues and the Creation of Prosperity, New York: Penguin Book, 1995. 